\title{
Sprawozdanie z warsztatów duszpasterskich (01-02.03.2011 r.)
}

Ewangelizacja stanowi centrum zbawczej działalności Kościoła. Istotną przeto staje się dbałość o zrodzenie się we wspólnocie eklezjalnej powołań kapłańskich i zakonnych. Z tą troską w dniach 1-2 marca 2011 roku Międzywydziałowa Katedra Teologii Katolickiej UwB zorganizowała warsztaty duszpasterskie dla księży Archidiecezji Białostockiej. Odbyły się one w Archidiecezjalnym Wyższym Seminarium Duchownym w Białymstoku pod hasłem: „Wybór drogi życiowej a sens życia: duszpasterstwo powołań" i zgromadziły ok. 200 uczestników.

Zaproszonymi prelegentami byli przybyli z Tarnowa ks. bp dr Wiesław Lechowicz oraz ks. dr Grzegorz Rzeźwicki, duszpasterz diecezjalny Liturgicznej Służby Ołtarza. Ich prelekcje stanowiły pierwszą część spotkania, drugą natomiast dyskusje w grupach.

Biskup Lechowicz przedstawił referat na temat „Duszpasterstwo powołań - powołaniem dzisiejszego duszpasterstwa”. Swoją prelekcję podzielił na dwie części. W pierwszej ukazał teologiczne uzasadnienie duszpasterstwa powołań, biorącego swój początek w praktyce pierwotnego Kościoła; w drugiej zaś wskazał metody tegoż duszpasterstwa realizowane w diecezji tarnowskiej.

We wstępie prelegent podkreślił naturę duszpasterstwa powołaniowego, które stanowi odzwierciedlenie egzystencji eklezjalnej. Za Janem Pawłem II podkreślił uprzywilejowaną formę życia chrześcijańskiego, jakim jest kapłaństwo, które nie niszczy wolności młodego człowieka, lecz stanowi realizację człowieczeństwa, ukierunkowanego na rzeczywistość nadprzyrodzoną i wartości duchowe („Pastores dabo vobis"), W dalszej części swoich rozważań, na podstawie wzorca pierwotnej gminy chrześcijańskiej, nakreślił cechy wspólnoty sprzyjającej odkryciu i pielęgnowaniu powołania przez młodego człowieka. Są nimi: trwanie na modlitwie i łamaniu Chleba, we wspólnocie z Bogiem i braćmi w wierze. „Ogniwem łączącym wspólnotę jest miłość. Jedynie w takiej wspólnocie młody człowiek jest w stanie wzrastać w duchu ofiarnej służby innym ludziom, która stanowi źródło powołania, będącego w swej istocie radosną, wolną i świadomą odpowiedzią na Boży dar" - mówił bp Lechowicz. Wyeksponował również cztery filary, które winny budować duszpasterstwo powołań. Zdaniem prelegenta są nimi: prymat Boga, zaangażowanie w życie Kościoła lokalnego, włączanie się w posługę charytatywną i świadectwo życia samych kapłanów.

W drugiej części swojego wystąpienia ks. Biskup ukazał formy duszpasterstwa powołań praktykowane w diecezji tarnowskiej. Wśród nich wymienił zaangażowanie księży w duszpasterstwie młodzieży, pracę w szkole, dbałość o rodzinną 
atmosferę wiary i miłości, działalność duszpasterstwa ministrantów, obecność lektorów podczas święceń prezbiteratu oraz funkcjonowanie Towarzystwa Przyjaciół Seminarium w Tarnowie.

Swój referat zakończył zachętą do promowania powołań w Kościele lokalnym, którą wyraził Benedykt XVI w orędziu na 48 Światowy Tydzień Modlitw o Powołania: „Zwłaszcza obecnie, gdy głos Pana zdaje się być zagłuszany przez inne głosy, a propozycja, by pójść za Nim i ofiarować Mu swoje życie może wydawać się zbyt trudna, każda wspólnota chrześcijańska i każdy wierzący powinni podjąć świadomie zadanie wspierania powołań. Jest ważne, by dodawać odwagi i wspierać tych, którzy przejawiają jasne znaki powołania do kapłaństwa czy do życia zakonnego, aby czuli wsparcie całej wspólnoty w powiedzeniu «tak» Bogu i Kościołowi”.

Drugi z prelegentów, ks. dr Grzegorz Rzeźwicki, skupił uwagę słuchaczy wokół zagadnienia „Duszpasterstwo ministrantów w służbie powołań”. Wychodząc od słów K. Rahnera, o „uratowaniu świata przed spoganieniem dzięki małym grupom", umotywował zasadność prowadzenia duszpasterstwa ministrantów, wpisujące się w działalność zbawczą Kościoła powszechnego. W wygłoszonym referacie podkreślił, że głównym celem duszpasterstwa ministrantów jest ich wychowanie. Biorąc za przykład diecezję tarnowską, przedstawił konkretne sposoby kształtowania osobowości ministrantów na różnych etapach ich rozwoju. Składają się na nie kilkuletni okres formacji, obejmujący Parafialną Szkołę Ministranta, Dekanalną Szkołę Lektora, Diecezjalną Szkołę Ceremoniarza, warsztaty liturgiczne, oazy ministranckie, coroczne dni skupienia w seminarium, a także współpracę z rodzicami ministrantów. Na kanwie rozważań wybrzmiały postulaty duszpasterskie pracy z młodzieżą: głębokie przeżycie przez młodych I Komunii św., regularne życie sakramentalne, diakonia modlitwy o powołania, zorganizowanie kółek różańcowych, opracowanie i korzystanie z modlitewnika LSO, wieloaspektowa współpraca z rodzicami i nauczycielami, którzy by ukazywali młodzieńcom perspektywę służenia przy ołtarzu po przystąpieniu do I Komunii św. Prelegent nakreślił nadto cechy duszpasterza Liturgicznej Służby Ołtarza. Są nimi: świadectwo wiary wartości, wskazywanie młodzieży Chrystusa, precyzyjny plan wychowania, postawa dialogu i otwarcia, stawianie wychowankom wymagań.

Po wysłuchaniu referatów uczestnicy spotkali się w trzech grupach dyskusyjnych. Pierwsza z nich, której przewodniczył ks. dr Józef Kozłowski, swoje rozważania skoncentrowała wokół roli rodziny w kształtowaniu powołań. Owocem dyskusji były wnioski: destrukcyjny wpływ antyświadectwa sakramentalnego rodziców, ogromna rola modlitwy rodzinnej, kształtującej duchowość młodego pokolenia.

Druga grupa, pod kierunkiem ks. mgr. lic. Jerzego Sęczka, poświęciła uwagę tematowi duszpasterstwa powołań w środowisku szkolnym. Dociekania podzielone zostały na trzy kwestie: szkoła jako instytucja z wyakcentowaniem wieloaspektowej współpracy szkoły i parafii w wychowaniu młodzieży; osobowość katechety, którą 
winna cechować otwartość i służebność - nie może on być jedynie nauczycielem religii, ale nade wszystko towarzyszem młodych; konieczność spotkań z rodzicami z podkreśleniem nieodzowności kształtowania ich samych.

Trzecia grupa, pod przewodnictwem ks. dr. Dariusza Sokołowskiego, skupiła się nad zagadnieniem roli parafii w duszpasterstwie powołaniowym, czego owocem stały się postulaty konieczności współpracy z rodzicami, pogłębienia kontaktu księży z wychowankami, podjęcia formacji duchowej ministrantów.

Podsumowując konferencję, jej przewodniczący - ks. dr hab. Adam Skreczko prof. UwB i UKSW, zwrócił uwagę zebranych na niezbędne elementy, składające się na duszpasterstwo powołań. Jako najistotniejsze wymienił zaangażowanie się młodych w życie Kościoła, świadectwo życia kapłańskiego, konieczność spotkań $z$ rodzicami i wypracowanie wspólnego modelu wychowawczego oraz znaczenie atmosfery rodzinnej w kształtowaniu powołań. Zwrócił się również z apelem do proboszczów o pisanie krytycznych opinii dla kandydatów ubiegających się o przyjęcie do seminarium.

W słowie kończącym konferencję ks. abp prof. dr hab. Edward Ozorowski podkreślił, jak ważna jest świadomość powołania w życiu człowieka, który poszukuje dróg samorealizacji. Jako wzór wskazał Maryję, która szła z ufnością $\mathrm{w}$ pielgrzymce wiary.

Anna Dzięgielewska Uniwersytet w Białymstoku 